\title{
Spatial trends in tourism within South Africa: The expected and the surprising
}

\author{
David H McKelly ${ }^{1}$, Christian M. Rogerson ${ }^{2}$, Elsona van Huysteen ${ }^{1}$, \\ Johan Maritz ${ }^{1}$, Mawande Ngidi ${ }^{1}$
}

\begin{abstract}
${ }^{1}$ Urban and Regional Planning, Spatial Planning and Systems, Built Environment, Council for Scientific and Industrial Research (CSIR), Stellenbosch, South Africa. dmckelly@csir.co.za

${ }^{2}$ School of Tourism and Hospitality, Faculty of Management, University of Johannesburg, South Africa.
\end{abstract}

DOI: http://dx.doi.org/10.4314/sajg.v6i2.7

\begin{abstract}
Several researchers have highlighted the spatial imbalances of the tourism sector in South Africa. It has been noted that this sector is highly concentrated spatially in terms of its distribution and in relation to its potential local impacts across the country. Although it is broadly understood that the tourism sector is geographically uneven, the lack of sector comparative data at municipal level may inhibit the wide spread use of geographically comparative analyses of the contribution of the various dimensions of tourism in the South African space economy.

The aim of this paper is to provide an indication of the value of such comparative analyses of the spatial trends and impacts of the tourism sector in local economies in South Africa. The discussion of the tourism space economy is based on an analysis of a local tourism database which contains details of the tourism performance of all local authorities in the country focussing on the period from 2001 to 2011.

Whilst the study confirms the important role of metropolitan areas, secondary and coastal cities and typical tourism destinations in the tourism space economy, it also highlights the significance of some local places/economies that are not traditionally associated with tourism, as well as illustrating the significance of tourism spend in the local economies of a range of municipalities that might not be part of the 'top' tourist destinations in South Africa.
\end{abstract}

Key Words: Spatial tourism trends, South Africa, space economy, tourism in local economy, trip purpose.

\section{Introduction}

The World Tourism Organization (WTO) defines tourism as the activities associated with travel away from a person's usual place or environment (WTO, 2000). Unlike agriculture or the manufacturing sector, tourism is a service industry with the product being consumed at the point of production. Given the tourist industry's structure in terms of a mix of large enterprises and many SMMEs that draw upon domestic and international visitors, and its components of natural and manmade attractions, tourism is complex, cross-sectoral and highly dynamic. In particular, as 
compared to the sectors of mining and manufacturing which relate to landscapes of production, the tourism sector must be understood as related to the understanding of places or landscapes of consumption.

The aim of this paper is to provide an indication of the value of geographically comparative analyses of the impact and spatial trends of the tourism sector in local economies in South Africa between 2001 and 2012. This will be done by first providing a short background on the role of tourism in South Africa and the mainstream understanding of its spatial distribution, followed by a short introduction to the analyses and lastly providing an overview of the more multi-dimensional nature of the tourism space economy.

Overall, the paper represents a further contribution to an emerging scholarship that seeks to understand the space economy of tourism in South Africa (see Visser 2007; Rogerson 2014, 2015).

\section{The role of tourism and its spatial distribution}

In terms of economic analysis, the tourism sector is highly distinctive in that it is not a sector that is formally classified as such in terms of the International Standard Industrial Classifications (Hatzichronoglou 1997). One important consequence of this situation is that there is often considerable uncertainty concerning the precise boundaries of the tourism economy and of how to measure its economic impact on employment creation or contribution to national GDP, as for example attempted within the NSDP, 2006 (The Presidency, 2006: 53-55). Among others, Christie et al. (2013: 43) stress that "in national accounts 'tourism' does not appear as a formal industry classification; its sub-categories, such as hotels and transport, are found within 'real estate', or aggregated under "transport, communications and storage"'. One tool for measurement is the Tourism Satellite Account (TSA) which in South Africa has been developed by Statistics South Africa to offer certain estimates of the direct contribution of tourism to GDP and employment creation.

Tourism is identified as one of the key industries driving change on the African continent, including South Africa (EDD, 2011). It is referred to as a potential jewel in the crown of many African countries, albeit an economic jewel that is in need of constant polishing and refinement (World Bank, 2010; EDD, 2011). From a base of 6.7 million visitors in 1990, sub-Saharan Africa attracted 33.1 million international arrivals in 2011. On a global scale tourism is growing faster in the world's emerging and developing regions than in the rest of the world. In a landmark recent study on tourism in Africa, Christie et al. (2013: 56) argue that tourism does not receive the credit it deserves in terms of its contributions towards the economic and social development of the continent. These authors identify (at least) ten principal reasons for developing tourism assets and poising a country for sustained economic growth of its tourism assets (Christie et al. 2013: 56). According to their findings the growth of tourism can: fuel the economic transformation of destinations; create many good jobs; show particular promise as a vehicle for the development of peripheral and remote regions; accelerate economic reforms that can help SMME development; be a 
catalyst for infrastructure improvements; increases domestic consumption and diversify exports; be a trigger for empowering women, youth and marginalised populations; be a stimulus for cultural heritage and environmental conservation; promote public-private partnerships; and improve the image of nations, regions and localities. This list could be extended even further to include such important contributions by tourism to: helping fight poverty; and improving social and economic inclusion.

Indeed, through the consumption of local products in tourist accommodation and through visitor expenditure outside that accommodation, tourism can be a catalyst for developing small businesses in the production and service sectors, increase demand for crafts and generate linkages to agriculture, fishing, food processing and light manufacturing. In addition, tourism can potentially "also create links in the informal sector" (Christie et al. 2013: 84-85).

Internationally, the expansion of tourism and recreational activities can result in positive impacts on local economies, in particular by generating economic and social development in marginal regions or rural areas. In developed economies, Jones and Munday (Jones et al. 2001: 2) observe that acknowledgement of "tourism and leisure as a fast growing industry has led to its identification as a potential driver of regeneration in economically disadvantaged localities". Overall, in terms of spatial development it is important to understand that "tourism can provide an economic base for a region whose only development options are its cultural and natural resources, whether coastal, mountain or wildlife" (Christie et al., 2013: 85).

Visser et al. (2004) describe tourism as the sector that was most adversely affected of all the sectors of South Africa's economy by the apartheid programs. Under the apartheid legislation the potential of domestic tourism was constrained as the majority Black population could not enjoy access to certain facilities and places, like beaches.

Several researchers have highlighted the spatial imbalances of the tourism sector in South Africa (Rogerson et al. 2004; Visser 2007; Visser et al. 2012) and that it is highly concentrated spatially in terms of its distribution and correspondingly in relation to its potential local impacts across the country. Even though regional tourism strategies highlight regional and local specific destinations and activities, comparative analyses usually highlight the role of municipalities in this important industry in terms of bednights and tourism spending patterns. It is postulated that the lack of sector comparative data at municipal level may have inhibited the wide spread use of geographically comparative analyses of the contribution of the various dimensions of tourism within municipalities across South Africa. Behind this knowledge gap is the weakness of data concerning the tourism sector as a whole in South Africa and in particular at a fine grained geographical scale of analysis.

\section{The Underlying Analysis}

This paper is based on a study conducted for the Economic Development Department (EDD) in 2014, and aimed at developing spatial perspectives for selected job drivers in support of the New Growth Path (NGP) (van Huyssteen et al. 2014). The analyses are based on a database which is 
derived from IHS Global Insight as part of its Regional eXplorer (IHS 2014). It is a consolidated platform of integrated databases that provides statistics down to a local municipal level.

The discussion of the tourism space economy draws upon an analysis of the local tourism database which contains details of the tourism performance of all local authorities in the country in respect of the number of tourism trips differentiated by purpose of trip and origin (domestic or international); bednights by origin of tourist (domestic or international); calculations of tourism spend; and, of the contribution of tourism spend to local gross domestic product. Data is available on an annual basis from 2001; in this analysis the focus is on the period 2001 and 2010, a decade which culminated in South Africa's hosting of the FIFA World Cup. The District Municipality (DM) and Local Municipality (LM) boundaries and names for 2011 were used in this analysis.

The data is based on the Tourism Satellite Account (TSA) model which was developed by the World Tourist Organisation (Frechtling 2012). The primary motivation behind TSA has been to compensate for the lack of reliable and comparable information to assess the role of tourism in national economies worldwide, and to develop a comprehensive and consistent set of principles to measure the economic impact of the tourist industry (Frechtling 2012).

In analysing this material, it should be understood at the outset that the measurement of tourism is not a perfect science. Although the TSA model can be a useful tool, care should be taken in interpreting the model calculations which use historic data as well as economic research to make assumptions and forecasts. Indeed, as a result of using a different methodology to that of the TSA, the estimated national contribution of tourism to the GDP of South Africa in the Global Insight data base (IHS 2014) is 6.3\% (2010) which is higher than that given in the provisional estimates made in 2010 by Statistics South Africa. This said, it is noted that the Global Insight data is closer than that of StatsSA to the estimates made by Saayman et al. (2012: 462) that tourism contributes an estimated 7\% of national GDP in South Africa.

In understanding the multi-dimensional nature of the tourism space economy the discussion will unfold through four sections of material. These will relate to the following:

- The spatial patterns of tourism trips and bednights as a whole.

- Differentiation of the geographical distribution of tourism trips and bednights by origin of tourist, whether domestic or international.

- The spatial patterns of trips by purpose of trip and differentiated into four sub-categories, namely leisure, business, visiting friends and relatives (VFR) and other.

- The geography of total tourism spend and the contribution of tourism to local economies.

For each of these four themes of discussion, a profile of the leading destinations in 2010 and a brief overview of major trends from 2001 to 2010, is presented.

Whilst it is acknowledged that 2010 was the year that South Africa hosted the FIFA Soccer World Cup and national and regional tourism figures would be influenced by that, the focus of the paper 
was not on analysing the impact of the event, nor on make statements about change in the industry per se. The focus is rather on a more nuanced understanding of the comparative spatial distribution and multi-dimensional nature of tourism.

\section{$4 \quad$ Study Results and Discussion}

\subsection{The Spatial Patterns of Tourism Trips and Bednights as a Whole}

In terms of the national picture of total trips and bednights (for both domestic and international tourists) which are the broadest indicators of tourism for different destinations; the ten leading destinations for trips and bednights in South Africa for 2010 are listed in Table 1. The destinations are ranked from the highest to lowest based on their percentage of national share.

Table 1: Ten Leading Destinations: All Tourist Trips and Bednights 2010

\begin{tabular}{|l|c|l|c|}
\hline \multicolumn{2}{|c|}{ Trips } & \multicolumn{2}{c|}{ Bednights } \\
\hline Destinations & $\begin{array}{c}\text { National Share } \\
(\%)\end{array}$ & Destinations & $\begin{array}{c}\text { National Share } \\
(\%)\end{array}$ \\
\hline Johannesburg & 8.34 & Johannesburg & 8.61 \\
\hline eThekwini & 7.90 & Cape Town & 8.31 \\
\hline Tshwane & 5.67 & eThekwini & 8.00 \\
\hline Cape Town & 5.58 & Tshwane & 5.96 \\
\hline Ekurhuleni & 4.56 & Ekurhuleni & 4.61 \\
\hline Ehlanzeni & 4.52 & Eden & 3.41 \\
\hline Nkangala & 3.17 & Ehlanzeni & 3.39 \\
\hline Mopani & 2.86 & Nelson Mandela Bay & 2.41 \\
\hline Capricorn & 2.80 & Nkangala & 2.32 \\
\hline Vhembe & 2.57 & Cape Winelands & 2.30 \\
\hline
\end{tabular}

In interpreting the results of the national picture of total trips and bednights the following key points emerge: The space economy of tourism is dominated by large metropolitan areas in terms of both trips and bednights. Beyond the metropolitan areas a number of distinctive District Municipalities emerge as key zones for tourism, they are: Ehlanzeni and Nkangala in Mpumalanga; Cape Winelands in Western Cape; and, Mopani, Vhembe, Waterberg and Capricorn in Limpopo. The greatest expansion in trips and bednights between 2001 and 2010 is recorded in the large cities/metropolitan areas.

\subsection{Differentiation of the Geographical Distribution of Tourism Trips and Bednights by Origin of Tourist (Domestic or International)}

The analysis results show that differences are evident in the space economy of domestic versus international tourism. The category of international tourism includes both long haul international 
travel and regional African visitors, who constitute $78 \%$ of current international travellers to South Africa. The ten leading destinations for domestic and International tourism together with their percentage of national share trips and bednights for 2010 are listed in Table 2.

Table 2: Ten leading (local) destinations for both Domestic and International Tourist, 2010.

\begin{tabular}{|l|c|l|c|l|l|l|c|}
\hline \multicolumn{3}{|c|}{ Domestic Tourist Destinations } & \multicolumn{3}{c|}{ International Tourist Destinations } \\
\hline \multicolumn{2}{|c|}{ Trips } & \multicolumn{2}{c|}{ Bednights } & \multicolumn{2}{c|}{ Trips } & \multicolumn{2}{c|}{ Bednights } \\
\hline Destination & $(\%)$ & Destination & $(\%)$ & Destination & $(\%)$ & Destination & $(\%)$ \\
\hline eThekwini & 8.85 & eThekwini & 9.53 & Johannesburg & 15.28 & Johannesburg & 14.67 \\
\hline Johannesburg & 6.59 & Johannesburg & 6.10 & Tshwane & 11.06 & Cape Town & 13.86 \\
\hline Cape Town & 5.20 & Cape Town & 6.01 & Cape Town & 7.10 & Tshwane & 10.56 \\
\hline Tshwane & 4.32 & Tshwane & 4.05 & Ekurhuleni & 7.08 & Ekurhuleni & 6.95 \\
\hline Ehlanzeni & 3.99 & Ekurheleni & 3.64 & Ehlanzeni & 6.62 & Eden & 6.05 \\
\hline Ekurhuleni & 3.93 & Ehlanzeni & 3.27 & eThekwini & 4.12 & eThekwini & 4.30 \\
\hline Nkangala & 3.18 & $\begin{array}{l}\text { Nelson Mandela } \\
\text { Bay }\end{array}$ & 2.98 & West Rand & 3.21 & Cape Winelands & 4.08 \\
\hline Capricorn & 2.91 & Buffalo City & 2.70 & Nkangala & 3.11 & Ehlanzeni & 3.66 \\
\hline Mopani & 2.89 & OR Tambo & 2.64 & Eden & 3.08 & West Rand & 3.11 \\
\hline Vhembe & 2.80 & Nkangala & 2.58 & Mopani & 2.75 & Overberg & 2.35 \\
\hline
\end{tabular}

Importantly, the top five domestic destinations account for $28 \%$ of trips and $29 \%$ of bednights. Cape Town has weakened in terms of volume as a domestic tourism destination since 2001 and between 2001-2010 records the largest absolute fall in domestic visitor trips. In terms of metropolitan areas, Mangaung is also in decline. eThekwini recorded the highest growth as a domestic tourism destinations and is followed by Johannesburg and Tshwane. The weakening of Cape Town as a domestic destination is reflected in a massive drop in domestic bednights. There are also declines in bednights at Mangauang and Ekurhuleni. Among DMs the largest absolute declines in bednights are for OR Tambo, Thabo Mafuntsanyane and significant falls for Frances Baard and Siyanda.

The top five international destinations account for $47 \%$ of all trips and $52 \%$ of bednights. This shows that international tourism is much more geographically concentrated than the domestic tourism patterns. The trend from 2001 in terms of trips for all metropolitan areas (except Buffalo City which has a marginal absolute decline) shows strong growth in international visitors with the highest expansion recorded in Johannesburg, Tshwane and Ekurhuleni. Among DMs the strongest growth of international trips is to Ehlanzeni and Waterberg, Eden and Mopani. There is an absolute decline in international tourist trips to Frances Baard, Siyanda and Namakwa. With respect to bednights similar patterns can be noted. The strongest DMs are Ehlanzeni, Waterberg, Eden, Cape Winelands, Capricorn while the weakest performances with the largest absolute declines are for Frances Baard, Siyanda and Namakwa. Cape Town recorded the largest growth of bednights by 
international visitors followed by Johannesburg, Ekurhuleni and eThekwini. All metropolitan areas show a growth in bednights for international visitors.

The metropolitan areas with Johannesburg, Cape Town and Tswhane are the leading international tourist destinations in South Africa while authorities such as Eden and Overberg make a strong contributions. eThekwini, Johannesburg and Cape Town are the top domestic tourist destinations but their growth is not as fast as smaller destinations.

\subsection{The Spatial Patterns of Trips by Purpose of Trip}

Spatial patterns of trips by "purpose of trip" are unpacked and discussed in this section in terms of four different tourism segments, namely: leisure, business, visiting friends and relatives (VFR), and other. The spatial distribution of the total number of trips for the different "purpose of trips" to South African for 2010 were mapped. The bar chart in Figure 1 shows the percentage contribution to national total for the business, leisure, visiting friends and relatives and "other" trips by district authorities for 2010.

Table 3: Fifteen Leading "Trips by Purpose" Destinations: 2010

\begin{tabular}{|l|c|l|c|l|l|l|c|}
\hline \multicolumn{2}{|c|}{ Business } & \multicolumn{2}{c|}{ Leisure } & \multicolumn{2}{c|}{ VFR } & \multicolumn{2}{c|}{ Other } \\
\hline Destination & $(\%)$ & Destination & $(\%)$ & Destination & $(\%)$ & Destination & $(\%)$ \\
\hline $\begin{array}{l}\text { City of } \\
\text { Johannesburg }\end{array}$ & 17.96 & $\begin{array}{l}\text { City of Cape } \\
\text { Town }\end{array}$ & 11.47 & eThekwini & 8.74 & $\begin{array}{l}\text { City of } \\
\text { Johannesburg }\end{array}$ & 17.96 \\
\hline $\begin{array}{l}\text { City of } \\
\text { Tshwane }\end{array}$ & 12.95 & $\begin{array}{l}\text { City of } \\
\text { Johannesburg }\end{array}$ & 10.30 & $\begin{array}{l}\text { City of } \\
\text { Johannesburg }\end{array}$ & 6.66 & City of Tshwane & 12.95 \\
\hline Ekurhuleni & 7.12 & City of Tshwane & 7.98 & Ekurhuleni & 4.65 & Ekurhuleni & 7.12 \\
\hline $\begin{array}{l}\text { City of Cape } \\
\text { Town }\end{array}$ & 6.80 & Ehlanzeni & 6.67 & $\begin{array}{l}\text { City of } \\
\text { Tshwane }\end{array}$ & 4.40 & $\begin{array}{l}\text { City of Cape } \\
\text { Town }\end{array}$ & 6.80 \\
\hline eThekwini & 6.44 & eThekwini & 6.53 & Ehlanzeni & 4.34 & eThekwini & 6.44 \\
\hline Ehlanzeni & 4.48 & Eden & 5.12 & $\begin{array}{l}\text { City of Cape } \\
\text { Town }\end{array}$ & 3.62 & Ehlanzeni & 4.48 \\
\hline Eden & 2.72 & Ekurhuleni & 4.45 & Vhembe & 3.45 & Eden & 2.72 \\
\hline Bojanala & 2.14 & Cape Winelands & 3.42 & Nkangala & 3.07 & Bojanala & 2.14 \\
\hline West Rand & 2.11 & Cacadu & 3.15 & Mopani & 3.06 & West Rand & 2.11 \\
\hline Cape Winelands & 2.05 & Waterberg & 2.83 & Bojanala & 2.51 & Cape Winelands & 2.05 \\
\hline Mangaung & 2.01 & Mopani & 2.38 & $\begin{array}{l}\text { UMgungundlo } \\
\text { vu }\end{array}$ & 2.41 & Mangaung & 2.01 \\
\hline Gert Sibande & 1.96 & West Rand & 2.31 & Capricorn & 2.36 & Gert Sibande & 1.96 \\
\hline Capricorn & 1.91 & Mangaung & 2.22 & Uthungulu & 2.31 & Capricorn & 1.91 \\
\hline $\begin{array}{l}\text { Nelson Mandela } \\
\text { Bay }\end{array}$ & 1.73 & Bojanala & 2.07 & O.R.Tambo & 1.96 & $\begin{array}{l}\text { Nelson Mandela } \\
\text { Bay }\end{array}$ & 1.73 \\
\hline Sedibeng & 1.68 & $\begin{array}{l}\text { Nelson Mandela } \\
\text { Bay }\end{array}$ & 2.04 & Amathole & 1.95 & Sedibeng & 1.68 \\
\hline
\end{tabular}




\subsubsection{Leisure}

The top fifteen destination for leisure is listed in table 3. The table (column: leisure) shows the percentage of national share of leisure trips by district authorities for 2010 .

Important points to note with regard to leisure trips are the following. The top five leisure destinations account for $41 \%$ of national share in 2001 and 2010 with a very slight decline in 2010 . The ten leading destinations, headed by Cape Town, are responsible for capturing an estimated 59\% of the national share of leisure trips. More than one-third of all leisure trips are accounted for by the four metropolitan areas of Cape Town, eThekwini, Tshwane and Johannesburg, a finding which reinforces the dominant role of these urban destinations in South Africa's tourism space economy. Outside of these areas, the leading DMs for leisure tourism are those around the Garden Route and the nature tourism attractions of Kruger Park, its surrounds and the region of Waterberg in Limpopo province. There is a relative consistency in leading leisure trip destinations between 2001 and 2010.

\subsubsection{Business Tourism}

The top fifteen destination for business is listed in table 3. The table (column: business) shows the percentage of national share of business trips by district authorities for 2010 .

With regard to business trips, the top five destinations account for $44 \%$ national share in 2001 and $49 \%$ share by 2010 . There is a high degree of concentration in business tourism in Gauteng. It is strongly concentrated upon the Johannesburg and Tshwane metropolitan areas followed by Cape Town, eThekwini and Ekurhuleni. In 2010 these five metropolitan areas were responsible for almost half of all national business trips. Together Johannesburg and Tshwane account for almost $30 \%$ of the national total. A key change since 2001 is the further strengthening of Johannesburg and Tshwane in importance and a greater concentration of business tourism on these two centres with a relative weakening of other metros (in particular Buffalo City). In terms of net change from 2001 to 2010, the overwhelming shift is towards Johannesburg and Tshwane and to a lesser extent eThekwini and Cape Town.

\subsubsection{Visiting Friends and Relatives (VFR) Tourism}

Among the least well-understood dimensions of the South African tourism economy is tourism related to visiting friends and relatives (VFR). It is known that VFR tourism is the largest element or most popular form of the domestic tourism sector and that the drivers of VFR tourism are markedly different to those of leisure or business tourism (Rule et al. 2004; Rogerson et al. 2005). The VFR market shows a close relationship to the national distribution of population and is the segment of tourism recognised to be most dominated by black tourists. The top fifteen destination for VFR is listed in table 3. The table (column: VFR) shows the percentage of national share of VFR trips by district authorities for 2010. The most important point to take cognisance of with regard to VFR is that the top five destinations for VFR account for $29 \%$ of national share in 2001 and $28 \%$ share in 2010 indicating a much more geographically widespread pattern of tourism than 
for leisure or business. Significantly, however, the list of leading destinations includes several district municipalities which incorporate small towns and rural areas of South Africa. The Vhembe DM and Mopani DM in Limpopo province emerge as significant tourism destinations for VFR tourism.

\subsubsection{Other Forms of Tourism}

The category "other" is mainly dominated by two forms of tourism, namely health tourism or religious (pilgrimage) tourism. It is by far the smallest category of tourism. The top fifteen destination for "other" is listed in table 3. The table (column: other) shows the percentage of national share of "other" trips by district authorities for 2010. The results indicate that the top five destinations for "other" tourist trips account for $46 \%$ share in 2001 but $39 \%$ share in 2010, there has been greater dispersion. The importance of certain DMs in Limpopo and KwaZulu-Natal which are focal points for religious tourism is evident. The significance of Johannesburg and Tshwane and other metros relates to the availability of medical facilities. Between 2001 and 2010 the most notable change is the rise of Umzinyathi which is a focus for pilgrimage.

\subsection{The Geography of Tourism Spend}

The analysis now turns to examine spatial patterns of tourism spend and to the relative contribution and importance of tourism to local economies. This is undertaken in terms of first examining the patterns of total tourism spend and then the relative significance of tourism spend in local areas as indexed by, firstly, average tourism spend per capita and, secondly, contribution of tourism spend as a share of local GDP.

\subsubsection{Spatial Patterns of Total Tourism Spend}

The map in figure 2 shows the total tourism spend as a percentage of national share for 2010 . The data confirms that the impacts of tourism in South Africa are highly concentrated in a small number of tourism destinations. The analysis of tourism spend in South African local authority areas reveals that the leading ten areas account for $54 . \%$ of total tourism spend in 2010 . It is evident that the greatest amount of tourism spend is captured by South Africa's major metropolitan areas rather than the country's secondary cities or small towns. Tourism is reinforcing the continued dominance of the core regions of the South African space economy. In 2010, 38.6\% of total national tourism spend accrues to the five metropolitan areas of Cape Town, Johannesburg, Tshwane, eThekwini, and Ekurhuleni. Although in terms of other indicators, Cape Town is not always the leading local authority area, in terms of the critical indicator of total tourism spend it is the leading destination and beneficiary of tourism growth in South Africa. DMs such as Eden, the Cape Winelands and Ehlanzeni are important nodes for tourism spend. Beyond these areas of note is also the relatively high share of tourism spend in Cacadu, Nkangala, West Rand and Overberg. Between 2001 and 2010 the top eight destinations in ranked order for total tourism spend remain 
unchanged, albeit the closing in of Johannesburg on the dominance of Cape Town. Beyond the stability of leading destinations in the tourism space economy, however, a number of significant shifts can be noted. In terms of metros both Nelson Mandela Bay and Buffalo City have increased in relative importance.

\subsubsection{Relative Significance of Tourism for Local Economies}

Using an indicator of average tourism per capita spend in local authorities, a picture emerges of those areas of South Africa in which the impact of tourism spend is most strongly experienced. The map in Figure 2 shows the average per capita tourism spend for 2001 and 2010.

The local authorities with the highest average per capita tourism spend illustrate the critical importance of tourism outside of the metropolitan areas. There are no metropolitan areas under the leading 20 destinations for 2010.

What emerges is that the local impacts of tourism are critical in many secondary towns and small towns across South Africa. Between 2001 and 2010 some significant changes are in evidence. The most dramatic is the rise in significance of the local impact of tourism for Prince Albert and also for Knysna, Stellenbosch, Mossel Bay, Oudtshoorn and George.

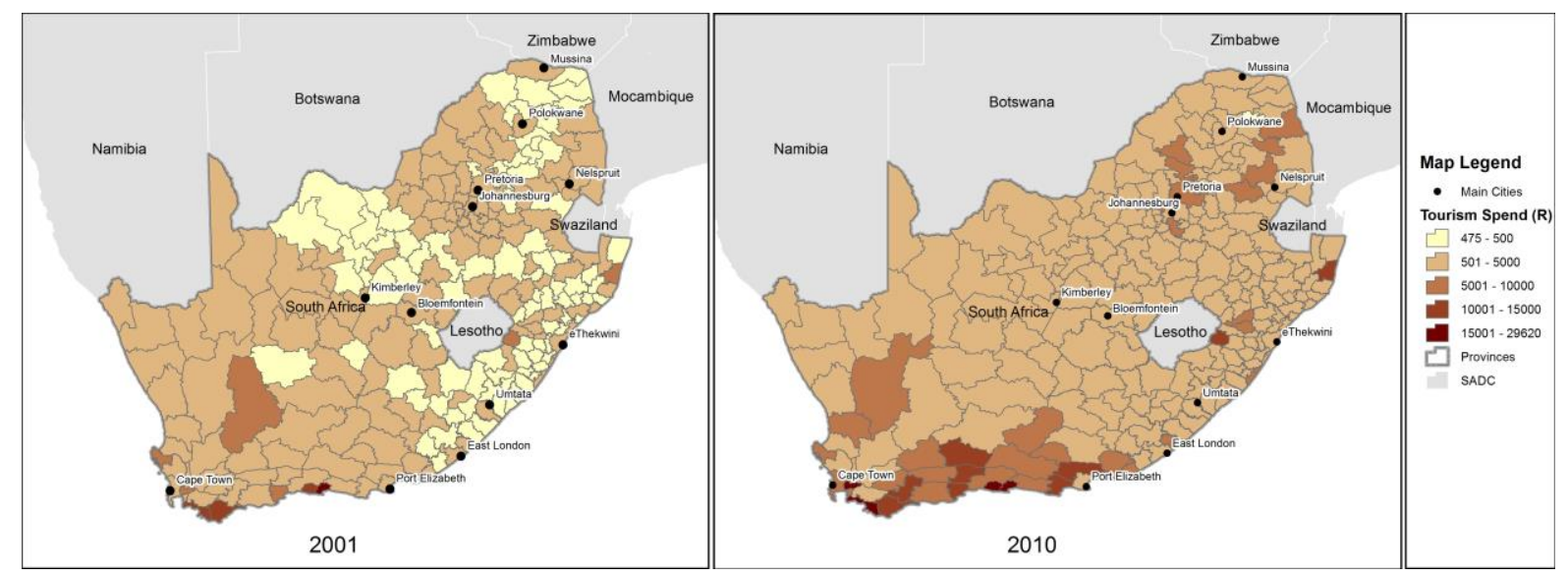

Figure 2: Average Tourism Spend per Capita

A second indicator of the relative importance of tourism for local economies is the estimated contribution of tourism spend as a contribution to local GDP. The maps in Figure 3 highlight the importance of tourism to the local GPD of the non-metropolitan areas. 


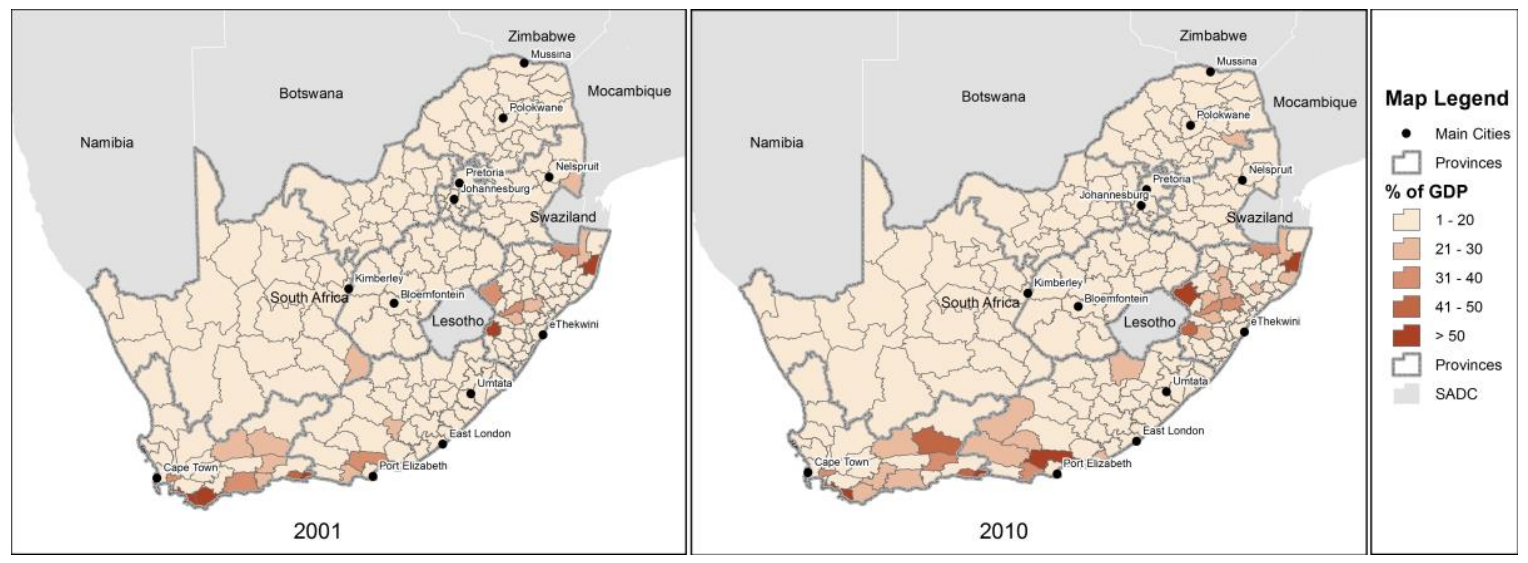

Figure 3: Tourism Spend as a Percentage of Local Gross Domestic Product

This analysis once again discloses the vital role of tourism in the non-metropolitan areas of South Africa. The findings reveal that in many secondary and small towns of the country tourism is a critical sector - often the lead sector - in local economies. In 2001 there were over 60 District and Local Municipalities where the proportion of tourism spend to total local GDP exceeded at least 15 percent. In the case of 12 local governments the contribution of tourism spend to local GDP is in excess of 30 percent; for eight local governments the contribution of tourism spend to local GDP is over 40 percent; and, for five local governments in 2010 tourism spend accounted for more than $50 \%$ of local GDP. Overall, these results point to the critical need for capacity development for tourism planning in local governments outside of the leading metropolitan areas of South Africa. As a whole in 2001, 106 local authorities (38\%) were above the national average of estimated tourism contribution to national GDP. By 2010, 167 local authorities (60\%) were above the national average. This shows the great dependence of South African local authorities upon the contribution of tourism to local economies. Between 2001 and 2010 a relative increase in tourism compared to the rest of the economic output in municipal economies is evident in several areas. Critically, several of these areas which are increasingly reliant upon tourism fall within the 27 Priority Rural Districts identified by the Department of Rural Development and Land Reform (DRDLR), including several former Homeland areas (DRDLR, 2013). The comparative analyses highlight the existing and potential role of tourism as a vehicle for regional development, even in the marginal areas of the South African space economy.

\section{Conclusions}

The analyses of national and international tourism trips and spending illustrate the significant role of metropolitan areas, secondary and coastal cities, and typical tourism destinations in the tourism space economy. Beyond the metropolitan areas a number of distinctive District Municipalities emerge as key zones for tourism, they are: Ehlanzeni and Nkangala in Mpumalanga; the Cape Winelands in the Western Cape; Mopani, Vhembe, Waterberg and Capricorn in Limpopo. The greatest growth in trips and bednights between 2001 and 2010 is recorded in the large cities/metropolitan areas. 
With regard to business trips, the top five destinations accounted for a $49 \%$ share by 2010 . There is a high degree of concentration in business tourism in Gauteng, followed by Cape Town and eThekwini. The spatially comparative analyses of the trips also illustrate the significance and different spatial pattern of trips generated through the visiting of friends and family across the South African landscape. In this regard it is evident that the more rural municipalities and especially former homeland areas play a significant role nationally, but also in terms of opportunities for local municipalities.

Considering the comparative analyses of tourism spend in relation to population and the economic output of municipalities, the significant role of tourism in areas that are not necessarily seen as top tourism destinations is also illustrated. The local municipalities with the highest average per capita tourism, as well as local municipalities where tourism spend seems significant in relation to economic output, emphasise the critical importance of tourism outside of the metropolitan areas.

The analyses point to the local impacts and significance of tourism, and the possible associated opportunities in a range of rural regions and many secondary and small towns across South Africa.

As indicated in the first part of the paper, it is widely believed that regional and local tourism strategies need to confront the traditional thinking around tourism destinations and opportunities. In support thereof the paper illustrates the significance and opportunities of the tourism industry in a range of municipalities across the South African landscape, and the value that alternative spatial perspectives and comparative analyses can provide in understanding the multi-dimensional nature of the tourism industry and its diverse national, regional, and local significance.

\section{References}

Christie, I., Fernandes, E., Messerli, H. \& Twining-Ward, L. 2013. Tourism in Africa: Harnessing Tourism for Growth and Improved Livelihoods. Washington DC: The World Bank.

Economic Development Department. 2011. The New Growth Path. Pretoria: Department of Economic Development.

Department of Rural Development and Land Reform. 2013. Priority Districts Analyses for Economic Transformation. Pretoria: Department of Rural Development and Land

Department of Tourism 2011. National Tourism Sector Strategy. Pretoria: Department of Tourism.

Douglas C., Frechtling, A. 2010. The tourism satellite account: A primer. Annals of Tourism Research 37 (1), 136-153.

Frechtling D. 2012: Forecasting Tourism Demand. London: Routledge IHS Global Insight. 2014. ReX Regional Explorer. Centurion: IHS Global Insight.

Hatzichronoglou, T. 1997, Revision of the High-Technology Sector and Product Classification", OECD Science, Technology and Industry Working Papers, No. 1997/02, OECD Publishing, Paris. http://dx.doi.org/10.1787/134337307632

Jones, C., Munday, M. 2001.Tourism and local economic development: Three case studies. Paper presented at the European Regional Science Association $41^{\text {st }}$ Annual Meeting, Zagreb, August.

Rogerson, C.M. 2014a. The Uneven Geography of Tourism in South Africa. African Journal of Hospitality, Tourism and Leisure, 3 (1), 1-15. 
Rogerson, C.M. and Lisa Z. 2005: 'Sho't left': promoting domestic tourism in South Africa, Urban Forum, $16,88-111$.

Rogerson, C.M. 2015. Tourism and Regional Development: The Case of South Africa's 'Distressed Areas'. Development Southern Africa, 32, 277-291.Rogerson C.M. \& Lisa, Z. (2005).'Sho't left': Promoting domestic tourism in South Africa. Urban Forum 16(2/3), 88-111.

Rogerson, C. M. \& Visser, G., Eds. 2004. Tourism and Development Issues in Contemporary South Africa. Pretoria: Africa Institute of South Africa.

Rule, S. Viljoen, J., Zama, S., Struwig, J., Langa, Z., Bouare, O. 2004. Visiting friends and relatives: South Africa's most popular form of domestic tourism. In C.M. Rogerson \& G. Visser (Eds.), Tourism and Development Issues in Contemporary South Africa, (pp. 78-101). Pretoria: Africa Institute of South Africa.

Saayman, M., Rossouw, R. and Krugell, W. 2012. The impact of tourism on poverty in South Africa. Development Southern Africa, 29, 462-487.

The Presidency. 2006. The National Spatial Development Perspective. The Presidency. South Africa

Van Huysteen, E., Maritz, J., McKelly D., Oranje M., Jordaan A., Rogerson C. 2014. RESOURCE DOCUMENT: TOWARDS SPATIAL PERSPECTIVES IN SUPPORT OF THE NGP. Viewed: June 2017, $<$ http://stepsa.org/pdf/projects/edd_tools/Draft\%20Resource\%20Document\%20Spatial\%20Perspectives\% 20NGP\%20v3.pdf >.

Visser, G. 2007. Geography of tourism. In R. George (ed.) Managing Tourism in South Africa (pp. 34-52). Cape Town: Oxford University Press.

Visser, G. \& Hoogendoorn, G. 2012. Uneven tourism development in South Africa: Another ongoing struggle Africa Insight 42 (2), 66-75.

Visser, G and Rogerson, CM. 2004. Researching the South African tourism and development nexus. GeoJournal, 60, 201-215

World Bank 2010. Kenya's Tourism: Polishing the Jewel. Washington DC: World Bank Africa Region Finance and Private Sector Department.

World Tourism Organisation. 2000. Tourism 2020 vision. Madrid; World Tourism Organisation. Madrid, WTO 